[計測 自 動制 御 学 会論文集

[Vol.49, No.10, 961/968 (2013) _

\title{
双対分解とゲーム理論に基づくリアルタイムプライシングによる 電力網の系統周波数制御
}

\author{
大久保 徳 雄**佐 藤 隆太郎** ·滑 川徹**,*** \\ Game Theoretic Real-time Pricing Based on Dual Decomposition and \\ Its Application to Load Frequency Control of Power Networks \\ Norio Okubo*, Ryutaro Sato** and Toru NameRikaWA**,***

\begin{abstract}
This paper deals with game theoretic real-time pricing method based on dual decomposition and its application to load frequency control of power networks. The proposed pricing method in this study aims to solve the constrained optimization problem consist of each player's utility and social welfare under selfish players. Selfish player's decision is a Nash equilibrium solution considering their own cost functions. We show this method can lead their own decision to social welfare maximization. Finally we show the effectiveness of the proposed methodology for load frequency control by several simulation results.
\end{abstract}

Key Words: power network, game theory, real-time pricing, dual decomposition

\section{1.はじめに}

近年，エネルギー問題，地球温暖化，脱原発といった問題 がますます注目されており，太陽光，風力といった，再生可 能エネルギーの電力網への導入が盛んに行なわれている。し かし, 電力網への再生可能エネルギーの大量導入は, 非人為 的な発電量の変動が大きいことから, 電力需給の均衡を保つ ことが難しい．需給のアンバランスは，周波数変動や電圧変 動を生じる原因となるため, 需要側と供給側とを分散的かつ 効率的に調整し, 最適な運用を行なう必要がある ${ }^{1)}$.

電力網の制御問題の一つとしては, 系統周波数制御問題 ${ }^{2)}$ がある。大規模システムである電力網に対して，集中制御は 難しいため, 近年では分散的な最適化 $\left.{ }^{3)}, 4\right)$ が研究されている. 分散制御において, 特に注目されているのは, 電気自動車, ヒートポンプ給湯器といった，需要家側の装置を積極的に制 御に用いる考え方 ${ }^{5)}$ である.ところが，需要家の意思決定は， 系統内の安定を考慮せず，利己的に行なわれると考えられる． そのため, 価格变動により間接的に需要を制御するディマン

* 慶應義塾大学大学院理工学研究科 横浜市港北区日吉 3-14-1

** 慶應義塾大学理工学部 横浜市港北区日吉 3-14-1

*** 独立行政法人科学技術振興機構, CREST 川口市本町 4-1-8

* Graduate School of Science and Engineering, Keio University, 3-14-1 Hiyoshi, Kohoku-ku, Yokohama

** Faculty of Science and Engineering, Keio University, 314-1 Hiyoshi, Kohoku-ku, Yokohama

*** JST, CREST, 4-1-8 Honcho, Kawaguchi (Received February 27, 2013)

(Revised June 27, 2013)
ドレスポンスという取り組みが注目されている，その目的の 一つとしては, 電力ピークを軽減し, 供給の負担を軽減する 負荷平準化 ${ }^{6), 7)}$ があげられるが，電力網の制御問題を主目的 としたプライシング手法 ${ }^{8)}$ 10) が存在する。本稿では, 供給 量の負担軽減を目指した負荷平準化，再生可能エネルギーの 大量導入による不安定性を解消するための系統周波数制御と いう二つの目的をプライシングにより達成することを目指す.

プライシング問題は一般的に最適化理論を用いて行なわれ ているが，最適なプライシングを行なうためには系統内にお ける需要家，供給者の行動を決定する情報をプライシングを 行なうオペレータが知る必要がある。しかし，このような集 中的な最適化は電力市場の規模やプライバシーの観点から難 しい，そのため，オペレータの取得情報を考慮した手法を考 えることが重要となる ${ }^{11)}$ ，オペレータの負担減少を考慮した アプローチの一つとして，価格の調整則にゲーム理論を考慮 した手法 ${ }^{12)}{ }^{13)}$ がある。ゲーム理論を考慮することで，負荷 平準化のみではなく, 系統周波数や, 電圧変動などの電力系 統全体の公共利益を反映させたプライシングが可能となる. ところが, 従来のゲーム理論を考慮したプライシング手法で は, 最適化問題を解く過程において, 制約条件が考慮されて いない。電力網を運用する際に，需要と供給のバランスをと るなどの物理的な制約を考慮しなければならないため，制約 条件を考慮した問題設定が望ましい.

従来のゲーム理論を考慮した手法においては，制約条件を 考慮した分散化は行なわれていなかったが，本稿における提 案手法では, 双対分解 ${ }^{14)}$ を考慮することで, 制約付き最適化 問題をゲーム問題として分散化し，各プレイヤーが利己的に 
ふるまった場合においても制約条件を考慮しつつ，各プレイ ヤーの利益と公共利益を合わせた社会全体の利益の最適化が 達成可能であることを証明する，提案手法を電力網に適用す る際は，公共利益を系統周波数，制約条件を需給の釣り合い とし，周波数制御と，負荷平準化を同時にプライシングによ り達成することを目標とする。またシミュレーション検証に おいては, 電力網における需要家と供給者の利已的な行動を モデル化し電力網の周波数制御モデルに対して適用すること で，提案手法の有効性を検証する.

最後に，本論文の構成を述べる．2 章においては，一般的な マルチプレイヤー問題にて最適化問題の定式化を行ない，利 己的なプレイヤーを考慮しても目標を達成できるようなプラ イシング手法の指針を示す． 3 章においては電力網の系統周 波数制御において，プレイヤーを電力の需要家と供給者とみ なして提案手法の適用を検討し，有効性をシミュレーション によって検証する。

\section{2. 問 題 設 定}

本章では, 一般的なマルチプレイヤー問題での定式化を扱う。 その概念図を，Fig. 1 に示す。システムには，プレイヤーが $n$ ，それらを管理するオペレータが $m$ だけ参加しているとし， $i$ 番目のプレイヤーを $P_{i}(i=1, \cdots, n), j$ 番目のオペレータを $O_{j}(j=1, \cdots, m)$ とする. $i$ 番目のプレイヤーは, 自身の利 益を表わす関数 $J_{i}\left(x_{i}\right)$ が最大となるように，自身の状態量 $x_{i}$ を決定する，パラメー夕 $\boldsymbol{z}$ は各プレイヤーの振る舞いにより 変動する公共利益を表わしており, $\boldsymbol{z}=H(\boldsymbol{x})=\sum_{i=1}^{n} H_{i}\left(x_{i}\right)$ にて変動が生じ，その評価関数を $J(\boldsymbol{z})$ とする．公共利益の 最適化は，各プレイヤーが利已的にふるまう限り達成されな い.そのため, $j$ 番目のオペレータが果たす役割は, 各プレイ ヤーの自身の利益のみを考慮した行動を公共利益の最適化お よび, 制約条件 $g_{j}(\boldsymbol{x})=0$ が達成されるように，プレイヤーを プライシングにより誘導するものとする，本章における主課 題は，オペレータがプレイヤーに対してどのようなプライシ ングを与えれば，プレイヤーの利已的な振る舞いを，公共利益 および制約の達成に向けて誘導できるかを考えることである。

Fig. 1 に示される問題設定は，(1) 式で定式化される．以 降，本稿では (1) 式を原問題と表記する，原問題が表わす 意味は，各プレイヤーの利益 $J_{i}\left(x_{i}\right)$ および，公共利益 $J(\boldsymbol{z})$ を加えた，システム全体の利益を表わすものである。その 制約として，各プレイヤーの振る舞いによる，公共利益の増 減 $\boldsymbol{z}=H(\boldsymbol{x})=\sum_{i=1}^{n} H_{i}\left(x_{i}\right)$ および, システム内の制約 $g_{j}(\boldsymbol{x})=0$ が定式化されている.

[問題 1]

$$
\begin{array}{ll}
\max _{\boldsymbol{x}} & \sum_{i=1}^{n} J_{i}\left(x_{i}\right)+J(\boldsymbol{z}) \\
\text { s.t. } & \boldsymbol{z}=H(\boldsymbol{x})=\sum_{i=1}^{n} H_{i}\left(x_{i}\right) \\
& g_{j}(\boldsymbol{x})=0 \quad j=1, \cdots, m
\end{array}
$$

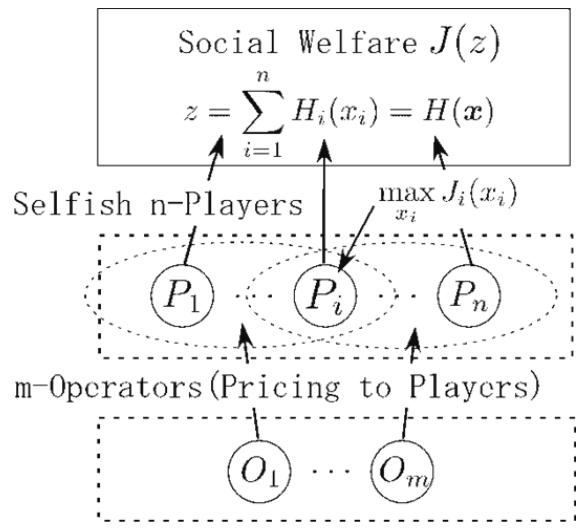

Fig. 1 Selfish players and operators

（1）式において，状態量，評価関数の定義は前述に従う。ここ で，原問題を凸最適化問題として記述するために以下の仮定 1 を設ける。

[仮定 1] $J_{i}(\cdot) \in C^{2}$ は狭義の凹関数, $[J \circ H](\cdot) \in C^{2}$ は 凹関数, $g_{j}(\cdot)$ は線形関数とする.

仮定 1 において $[J \circ H](\cdot)$ は $J(\boldsymbol{z})$ と $H(\boldsymbol{x})$ の合成関数で ある。

また，原問題は以下のような双対問題として書き表わすこ とができる。

$$
\min _{\boldsymbol{\lambda}} \max _{\boldsymbol{x}} \sum_{i=1}^{n} J_{i}\left(x_{i}\right)+[J \circ H](\boldsymbol{x})+\sum_{j=1}^{m} \lambda_{j} g_{j}(\boldsymbol{x})
$$

ここでベクトル $\boldsymbol{\lambda}$ の定義は $\boldsymbol{\lambda}=\left[\lambda_{1}, \cdots, \lambda_{m}\right]$ とする. (2) 式 において, ラグランジュ関数は, $L(\boldsymbol{x}, \boldsymbol{\lambda})=\sum_{i=1}^{n} J_{i}\left(x_{i}\right)+$ $[J \circ H](\boldsymbol{x})+\sum_{j=1}^{m} \lambda_{j} g_{j}(\boldsymbol{x})$. である. 双対問題において, 以 下の鞍点解と原問題の最適解は一致する.

$$
L\left(\boldsymbol{x}, \boldsymbol{\lambda}^{*}\right) \leq L\left(\boldsymbol{x}^{*}, \boldsymbol{\lambda}^{*}\right) \leq L\left(\boldsymbol{x}^{*}, \boldsymbol{\lambda}\right)
$$

(2) 式を，前述の利己的プレイヤーという問題設定を考慮し て，分割して考える。分割された問題において $i$ 番目のプレ イヤーが得られる利益は以下のようになり, 以降これを利益 関数と呼称する.

$$
\mathcal{C}_{i}\left(x_{i}, x_{-i}, \boldsymbol{\lambda}\right)=J_{i}\left(x_{i}\right)+\pi_{i}\left(x_{i}, x_{-i}, \boldsymbol{\lambda}\right)
$$

(4) 式において， $\pi_{i}$ はオペレー夕により，各プレイヤーへと 与えられる付加コストである。オペレータは，公共利益，制 約条件を考慮し，プライシングにより各プレイヤーの行動を 原問題の最適化へと誘導する役割を果たす。一 $i$ は相手プレイ ヤーを表わす集合であり,$-i=\{1, \ldots, i-1, i+1, \ldots, n\}$ と定義する．各プレイヤーは付加コストが与えられた新たな 目的関数である利益関数 $\mathcal{C}_{i}\left(x_{i}, x_{-i}, \boldsymbol{\lambda}\right)$ を最大化するように 行動する。

ラグランジュ乗数の最適化は, $j$ 番目のオペレータにより 行なわれる。各オペレータの決定は，コスト関数 $\mathcal{O}_{j}\left(\boldsymbol{x}, \lambda_{j}\right)$ の最小化となる。 


$$
\mathcal{O}_{j}\left(\boldsymbol{x}, \lambda_{j}\right)=\lambda_{j} g_{j}(\boldsymbol{x})
$$

(4) 式と (5) 式より構成される分解後の問題は, $n+m$ プレ イヤーにより構成される非協力ゲーム問題としてとらえるこ とができ, その解は, 以下に示すナッシュ均衡になる.

$$
\begin{array}{r}
\mathcal{C}_{i}\left(x_{i}^{*}, x_{-i}^{*}, \lambda^{*}\right) \geq \mathcal{C}_{i}\left(x_{i}, x_{-i}^{*}, \lambda^{*}\right) \\
\mathcal{O}_{j}\left(x_{i}^{*}, x_{-i}^{*}, \lambda_{j}^{*}\right) \leq \mathcal{O}_{j}\left(x_{i}^{*}, x_{-i}^{*}, \lambda_{j}\right)
\end{array}
$$

以上より，われわれの目的は双対問題の鞍点解とナッシュ均 衡解が一致するような付加コスト $\pi_{i}$ の条件を見つけること であるとわかる。この目的を達成する本研究の主結果として, 以下の定理 1 が得られた。

《定理 1》 仮定 1 が成り立ち, プレイヤー $i$ に対する付加コ ス卜関数 $\pi_{i}\left(x_{i}, x_{-i}, \boldsymbol{\lambda}\right)$ が与えられたとする. (4) 式で定義さ れる $\mathcal{C}_{i}\left(x_{i}, x_{-i}, \boldsymbol{\lambda}\right)$ 抢よび, $(5)$ 式で定義される $\mathcal{O}_{j}\left(\boldsymbol{x}, \lambda_{j}\right)$ の ナッシュ均衡解が双対問題 (2) 式の鞍点解となる必要十分条 件は, 以下の $(8)$ 式を満たす連続な任意関数 $F_{i}\left(x_{-i}, \boldsymbol{\lambda}\right)$ が存 在することである.

$$
\begin{aligned}
\pi_{i}\left(x_{i}, x_{-i}, \boldsymbol{\lambda}\right)= & {[J \circ H]\left(x_{i}, x_{-i}\right)+\sum_{j=1}^{m} \lambda_{j} g_{j}\left(x_{i}, x_{-i}\right) } \\
& +F_{i}\left(x_{-i}, \boldsymbol{\lambda}\right)
\end{aligned}
$$

[Proof］まず，必要性を示す。鞍点解 (3) 式と,ナッシュ均 衡解 (6) 式と (7) 式が等しいと仮定する. 仮定 1 より, 原問 題は凸最適化問題であり，KKT 条件を満たす最適解が唯一 存在する. $\left(\bar{x}_{i}, \bar{x}_{-i}, \bar{\lambda}\right)$ をナッシュ均衡解とすると, 以下の式 を得る。

$$
\begin{aligned}
\frac{\partial \mathcal{C}_{i}\left(\bar{x}_{i}, \bar{x}_{-i}, \overline{\boldsymbol{\lambda}}\right)}{\partial x_{i}} & =\frac{\partial}{\partial x_{i}}\left(J_{i}\left(\bar{x}_{i}\right)+\pi_{i}\left(x_{i}, x_{-i}, \boldsymbol{\lambda}\right)\right) \\
& =0
\end{aligned}
$$

ここで，鞍点解を $\left(\boldsymbol{x}^{*}, \boldsymbol{\lambda}^{*}\right)$ とすると，(2) 式の KKT 条件は 以下のようになる.

$$
\begin{aligned}
& \frac{\partial L\left(\boldsymbol{x}^{*}, \lambda^{*}\right)}{\partial x_{i}} \\
= & \frac{\partial}{\partial x_{i}}\left(\sum_{i=1}^{n} J_{i}\left(x_{i}^{*}\right)+[J \circ H](\boldsymbol{x})+\sum_{j=1}^{m} \lambda_{j}^{*} g_{j}\left(\boldsymbol{x}^{*}\right)\right) \\
= & 0
\end{aligned}
$$

仮定より，(2) 式の鞍点解と (6), (7) 式のナッシュ均衡解は 一致する. そのための付加コスト $\pi_{i}\left(\bar{x}_{i}, \bar{x}_{-i}, \bar{\lambda}\right)$ の条件は, 以下.

$$
\begin{aligned}
& \frac{\partial \pi_{i}\left(\bar{x}_{i}, \bar{x}_{-i}, \boldsymbol{\lambda}\right)}{\partial x_{i}} \\
& =\frac{\partial}{\partial x_{i}}\left([J \circ H]\left(\bar{x}_{i}, \bar{x}_{-i}\right)+\sum_{j=1}^{m} \bar{\lambda}_{j} g_{j}\left(\bar{x}_{i}, \bar{x}_{-i}\right)\right)
\end{aligned}
$$

以上より，以下の (12) 式が導かれる.

$$
\begin{aligned}
\pi_{i}\left(x_{i}, x_{-i}, \boldsymbol{\lambda}\right)= & {[J \circ H]\left(x_{i}, x_{-i}\right)+\sum_{j=1}^{m} \lambda_{j} g_{j}\left(x_{i}, x_{-i}\right) } \\
& +F_{i}\left(x_{-i}, \boldsymbol{\lambda}\right)
\end{aligned}
$$

ラグランジュ乗数に関しても同様に導出される。コスト関 数 $\mathcal{O}_{j}\left(x, \lambda_{j}\right)$ に関するナッシュ均衡解は,

$$
\frac{\partial \mathcal{O}_{j}\left(x, \lambda_{j}\right)}{\partial \lambda_{j}}=0
$$

ラグランジュ乗数に関する $\mathrm{KKT}$ 条件は,

$$
\frac{\partial L(\boldsymbol{x}, \boldsymbol{\lambda})}{\partial \lambda_{j}}=g_{j}(\boldsymbol{x})=0
$$

よって，条件を満たすコスト関数は，

$$
\mathcal{O}_{j}\left(x, \lambda_{j}\right)=\lambda_{j} g_{j}(\boldsymbol{x})
$$

以上より，ラグランジュ乗数に関しても確認ができ，十分性 が示された。

つぎに, 十分性を示す。付加コスト $\pi_{i}\left(x_{i}, x_{-i}, \lambda\right)$ が $(8)$ 式 を満たすとする。また， $\left(x_{i}^{\star}, x_{-i}^{\star}, \lambda^{\star}\right)$ が以下の不等式を満た すとする.

$$
\mathcal{C}\left(x_{i}^{\star}, x_{-i}^{\star}, \lambda^{\star}\right)<\mathcal{C}\left(x_{i}, x_{-i}^{\star}, \lambda^{\star}\right)
$$

$\mathcal{C}\left(x_{i}^{\star}, x_{-i}^{\star}, \lambda^{\star}\right)$ の定義より, (16) 式は以下のように計算される.

$$
\begin{aligned}
& J_{i}\left(x_{i}^{\star}\right)+[J \circ H]\left(x_{i}^{\star}, x_{-i}^{\star}\right)+\sum_{j=1}^{m} \lambda_{j}^{\star} g_{j}\left(x_{i}^{\star}, x_{-i}^{\star}\right)+F_{i}\left(x_{-i}^{\star}, \lambda^{\star}\right) \\
& <J_{i}\left(x_{i}\right)+[J \circ H]\left(x_{i}, x_{-i}^{\star}\right)+\sum_{j=1}^{m} \lambda_{j}^{\star} g_{j}\left(x_{i}, x_{-i}^{\star}\right)+F_{i}\left(x_{-i}^{\star}, \lambda^{\star}\right) \\
& \Leftrightarrow J_{i}\left(x_{i}^{\star}\right)+J_{-i}\left(x_{-i}^{\star}\right)+[J \circ H]\left(x_{i}^{\star}, x_{-i}^{\star}\right)+\sum_{j=1}^{m} \lambda_{j}^{\star} g_{j}\left(x_{i}^{\star}, x_{-i}^{\star}\right) \\
& <J_{i}\left(x_{i}\right)+J_{-i}\left(x_{-i}^{\star}\right)+[J \circ H]\left(x_{i}, x_{-i}^{\star}\right)+\sum_{j=1}^{m} \lambda_{j}^{\star} g_{j}\left(x_{i}, x_{-i}^{\star}\right) \\
& \Leftrightarrow L\left(x_{i}^{\star}, x_{-i}^{\star}, \lambda^{\star}\right)<L\left(x_{i}, x_{-i}^{\star}, \lambda^{\star}\right)
\end{aligned}
$$

$\left(x_{i}^{\star}, x_{-i}^{\star}, \lambda^{\star}\right)$ は双対問題 $(2)$ の鞍点解とはなり得ないことが わかる。よって, 鞍点解とナッシュ均衡解は一致する.

ラグランジュ乗数に関しても同様に導出される. $\left(x_{i}^{\star}, x_{-i}^{\star}, \lambda^{\star}\right)$ が以下の不等式を満たすと仮定する.

$$
\mathcal{O}_{j}\left(x_{i}^{\star}, x_{-i}^{\star}, \lambda^{\star}\right)>\mathcal{O}_{j}\left(x_{i}, x_{-i}^{\star}, \lambda^{\star}\right)
$$

$\mathcal{O}\left(x_{i}^{\star}, x_{-i}^{\star}, \lambda^{\star}\right)$ ，の定義より，(18) 式は以下のように計算さ れる.

$$
\begin{aligned}
& \lambda_{j}^{\star} g_{j}\left(x_{i}^{\star}, x_{-i}^{\star}, \lambda_{j}^{\star}\right)>\lambda_{j} g_{j}\left(x_{i}^{\star}, x_{-i}^{\star}\right) \\
& \Leftrightarrow \sum_{i=1}^{n} J_{i}\left(x_{i}^{\star}\right)+[J \circ H]\left(\boldsymbol{x}^{\star}\right)+\lambda_{j} g_{j}\left(\boldsymbol{x}^{\star}\right)+\lambda_{-j}^{\star}\left(\boldsymbol{x}^{\star}\right) \\
& >\sum_{i=1}^{n} J_{i}\left(x_{i}^{\star}\right)+[J \circ H](\boldsymbol{x})+\lambda_{j} g_{j}\left(\boldsymbol{x}^{\star}\right)+\lambda_{-j}^{\star}\left(\boldsymbol{x}^{\star}\right) \\
& \Leftrightarrow L\left(\boldsymbol{x}^{\star}, \boldsymbol{\lambda}^{\star}\right)>L\left(\boldsymbol{x}^{\star}, \boldsymbol{\lambda}\right)
\end{aligned}
$$

$\left(x_{i}^{\star}, x_{-i}^{\star}, \lambda^{\star}\right)$ は, (2) の鞍点解とはなりえない. よって, 鞍 点解とナッシュ均衡は一致する.

\section{3. 電力系統と系統周波数制御}

本章では，提案したプライシング手法の電力網の系統周波 
数制御への応用について考える. 今回考慮する電力網モデル は, Fig. 2 に示すような 2 エリアから構成されるマイクログ リッドを考える，各エリアの電力容量は $200 \mathrm{MW}$ とし，単位 法における基準值とする。グリッド同士は，連結しており， 電力潮流 $P_{t i e}$ による干渉があるとする，各グリッドは，供給 者, 需要家, ISO (Independent System Operator) から構成 されているとする。ここでいう需要家は，エリア内に存在す るすべての需要家を仮想的に一つのプレイヤーとみなして考 えている，また，供給者に関しても同様に供給者の発電機は すべて同期運転しており，仮想的に一つの発電機とみなせる とする. 二つのエリア $i(i=1,2)$ の需要家は, 付加コスト $\pi_{d_{i}}$ を考慮して, 電力消費量 $x_{d_{i}}$ を決定する，供給者の振る 舞いであるが, 付加コスト $\pi_{s_{i}}$ を考慮して, 電力供給量 $x_{s_{i}}$ を決定する，供給者の装置としてはガスタービン発電機を想 定しているが, 従来の系統周波数制御 (LFC) を行なう機能を 有しており，供給者の一部の発電機はそのために運用されて いるものとする，今回は TBC 方式を採用し，ブロック線図 にて Fig. 3 上部に示している。独立系統運用機関 (ISO) は, エリア内の需要家および供給者にプライシングを行なう非営 利の第 3 機関とする。また, 風力発電機にはコントローラー が搭載されておらず，出力調整は行なえないものとする.

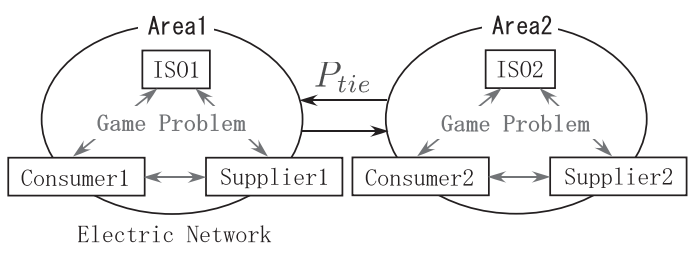

Fig. 2 Connection of areas

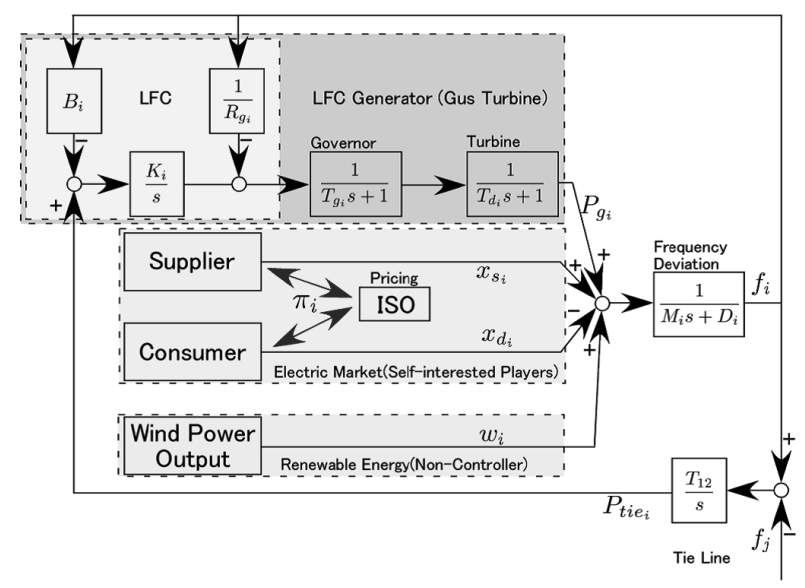

Fig. 3 Model of each area

\section{1 電力網のモデル化}

Fig. 3 に各エリアの詳細を示す。この図を基に, 公共利益 $\boldsymbol{z}$ のモデル化をしていく.エリア間潮流変動 $P_{t i e}$ に関しては, (20) 式で定式化した. 需給の偏差によって生じる周波数変動 $f_{i}$ に関しては，(21) 式で定式化した。(21) 式における变数 の定義であるが， $P_{g i}$ は供給者が LFC 発電機として運転し
ているガスタービン発電機の出力を表わしており，供給者の トータルの発電量は, $S_{i}^{\text {total }}=P_{g i}+x_{s_{i}}$ となる. $w_{i}$ は風力 発電出力を表わしており，コントローラーが搭載されていな いため，出力調整は行なわれないとする，ガスタービン発電 機は，ガバナとタービンからなり，それぞれの動特性を，(22) 式，(23) 式でそれぞれ一次系で模擬した。 (24) 式はエリア $i$ の LFC 出力指令值を表わしている。

$$
\begin{aligned}
\dot{P}_{t i e_{i}}= & \sum_{j \in \mathcal{N}_{i}} T_{i j}\left(f_{j}-f_{i}\right) \\
\dot{f}_{i}= & -\frac{D_{i}}{M_{i}} f_{i}+\frac{1}{M_{i}} P_{g i}+\frac{1}{M_{i}} x_{s_{i}}-\frac{1}{M_{i}} x_{d_{i}} \\
& +\frac{1}{M_{i}} P_{t i e_{i}}+\frac{1}{M_{i}} w_{i} \\
\dot{P}_{g_{i}}= & -\frac{1}{T_{d_{i}}} P_{g_{i}}+\frac{1}{T_{d_{i}}} x_{g v_{i}} \\
\dot{x}_{g v_{i}}= & -\frac{1}{R_{g_{i}} T_{g_{i}}} f_{i}-\frac{1}{T_{g_{i}}} x_{g v_{i}}+\frac{1}{T_{g_{i}}} U_{A R_{i}} \\
\dot{U}_{A R_{i}}= & K_{i} P_{t i e_{i}}-B_{i} K_{i} f_{i}
\end{aligned}
$$

ただし $\mathcal{N}_{i}$ はエリア $i$ と隣接しているエリアの集合を表わす. ベクトル $\boldsymbol{z}_{i}=\left[\begin{array}{lllll}P_{t i e_{i}} & f_{i} & P_{g_{i}} & x_{g v_{i}} & U_{A R_{i}}\end{array}\right]^{T}$ を定義し, サンプ ル時間 $T$ で零次ホールドにより離散化し, $(25)$ 式とする.

$$
\begin{aligned}
\boldsymbol{z}_{i}(t+1)= & \boldsymbol{E}_{i} \boldsymbol{z}_{i}(t)+\boldsymbol{C}_{i} x_{s_{i}}(t)-\boldsymbol{C}_{i} x_{d_{i}}(t) \\
& +\sum_{j \in \mathcal{N}_{i}} \boldsymbol{E}_{i j} \boldsymbol{z}_{j}(t)+\boldsymbol{C}_{i} w_{i}(t)
\end{aligned}
$$

(25) 式において, 離散化を行なう前の行列 $\boldsymbol{E}_{i}, \boldsymbol{C}_{i}, \boldsymbol{E}_{i j}$ をそ れぞれ, 行列 $\boldsymbol{E}_{c i}, \boldsymbol{C}_{c i}, \boldsymbol{E}_{c i j}$ として以下に示す.

$$
\begin{aligned}
\boldsymbol{E}_{c i}= & {\left[\begin{array}{ccccc}
0 & -T_{i j} & 0 & 0 & 0 \\
\frac{1}{M_{i}} & \frac{-D_{i}}{M_{i}} & \frac{1}{M_{i}} & 0 & 0 \\
0 & 0 & \frac{-1}{T_{d_{i}}} & \frac{1}{T_{d_{1}}} & 0 \\
0 & \frac{-1}{R_{g_{i}} T_{g_{i}}} & 0 & \frac{-1}{T_{g 1}} & \frac{1}{T_{g_{1}}} \\
K_{i} & -B_{i} K_{i} & 0 & 0 & 0
\end{array}\right] } \\
\boldsymbol{C}_{c i}= & {\left[\begin{array}{lllll}
0 & \frac{1}{M_{i}} & 0 & 0 & 0
\end{array}\right]^{\mathrm{T}} } \\
\boldsymbol{E}_{c i j}= & {\left[\begin{array}{ccccc}
0 & T_{i j} & 0 & 0 & 0 \\
0 & 0 & 0 & 0 & 0 \\
0 & 0 & 0 & 0 & 0 \\
0 & 0 & 0 & 0 & 0 \\
0 & 0 & 0 & 0 & 0
\end{array}\right] }
\end{aligned}
$$

これで，公共利益を表わす変数 $\boldsymbol{z}=\left[\boldsymbol{z}_{1}^{\mathrm{T}}, \boldsymbol{z}_{2}^{\mathrm{T}}\right]^{\mathrm{T}}$ が定式化で きた. 変数 $z$ を見ると, 潮流変動, 系統周波数変動, $\mathrm{LFC}$ 発 電機の稼働量を公共利益として設けていることがわかる.

電力網モデルに関して設定したパラメータを Table 1 に 示す。これらのパラメータに関しては文献 5), 文献 15) を参 考にして決定した.

\section{2 各プレイヤーのモデル化}

電力市場に参加する需要家, 供給者, ISO のモデル化を行 なう。電力網全体の利益を表わす，社会厚生関数を以下のよ うに定義する. 
Table 1 Model parameters

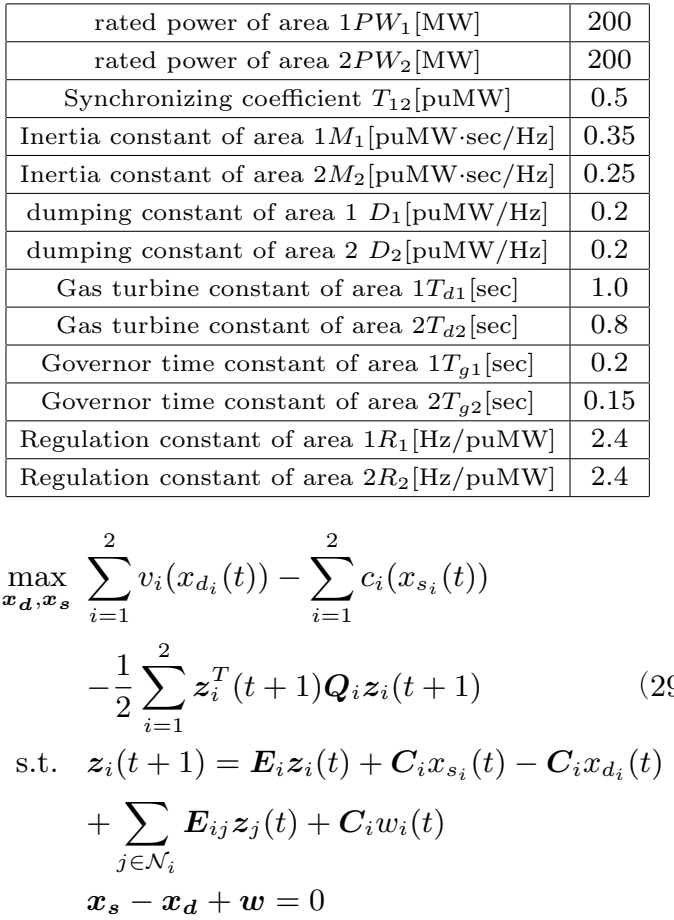

(1) 式と (29) 式の対応関係は以下のようになっている.

$$
\begin{aligned}
\boldsymbol{z} & =\left[\boldsymbol{z}_{1}^{\mathrm{T}} \boldsymbol{z}_{2}^{\mathrm{T}}\right]^{\mathrm{T}} \\
\boldsymbol{x} & =\left[x_{d_{1}} x_{d_{2}} x_{s_{1}} x_{s_{2}}\right]^{\mathrm{T}} \\
\sum_{i=1}^{n} J_{i}\left(x_{i}\right) & =\sum_{i=1}^{2} v_{i}\left(x_{d_{i}}(t)\right)-\sum_{i=1}^{2} c_{i}\left(x_{s_{i}}(t)\right) \\
{[J \circ H](\boldsymbol{x}) } & =-\frac{1}{2} \sum_{i=1}^{2} \boldsymbol{z}_{i}^{\mathrm{T}}(t+1) \boldsymbol{Q}_{i} \boldsymbol{z}_{i}(t+1) \\
\boldsymbol{g}(\boldsymbol{x}) & =\boldsymbol{x}_{\boldsymbol{s}}-\boldsymbol{x}_{\boldsymbol{d}}+\boldsymbol{w}
\end{aligned}
$$

また，(29) 式において $v_{i}\left(x_{d_{i}}(t)\right)$ は効用関数と呼ばれ需要家 $i$ が電力を $x_{d_{i}}(t)$ 消費したときに得ることのできる金銭的満 足度を表わす関数であり， $c_{i}\left(x_{s_{i}}(t)\right)$ はコスト関数と呼ばれ 供給者 $i$ が電力を $x_{s_{i}}(t)$ 生産したときに要する費用を表わす 関数である.

$x_{d_{i}}(t), x_{s_{i}}(t)$ の決定は各プレイヤーにより，それぞれ自身 の効用関数 $v_{i}\left(x_{d_{i}}(t)\right)$, コスト関数 $c_{i}\left(x_{s_{i}}(t)\right)$ のみを考慮し, 利已的になされるものとする. 利已的な決定を避けるため, プ ライシングを行なうことを考えたい. (29) 式のうち, 原問題 の $[J \circ H]$ に相当する部分は, $-\frac{1}{2} \sum_{i=1}^{2} \boldsymbol{z}_{i}^{T}(t+1) \boldsymbol{Q}_{i} \boldsymbol{z}_{i}(t+1)$ であるが, 定理 1 に従って付加コストを計算すると, 需要家 の新たな利益関数 $\mathcal{C}_{d_{i}}\left(x_{d_{i}}(t), x_{-d_{i}}(t)\right)$ は以下のようになる. $x_{-d_{i}}$ の定義は, エリア $i$ の需要家にとっての相手プレイヤー を表わしており，たとえば $x_{-d_{1}}=\left\{x_{d_{2}}, x_{s_{1}}, x_{s_{2}}\right\}$ である.

$$
\begin{aligned}
& \mathcal{C}_{d_{i}}\left(x_{d_{i}}(t), x_{-d_{i}}(t)\right) \\
= & v_{i}\left(x_{d_{i}}(t)\right)+[J \circ H]\left(x_{d_{i}}(t), x_{-d_{i}}(t)\right) \\
& +\boldsymbol{\lambda}^{T}(t) \boldsymbol{g}\left(x_{d_{i}}(t), x_{-d_{i}}(t)\right)+F_{d_{i}}\left(x_{-i}, \boldsymbol{\lambda}\right)
\end{aligned}
$$

$[J \circ H]\left(x_{d_{i}}, x_{-d_{i}}\right)$ と $\boldsymbol{g}\left(x_{d_{i}}, x_{-d_{i}}\right)$ を展開し, 任意関数
$F_{i}\left(x_{-d_{i}}, \boldsymbol{\lambda}\right)$ を用いて $x_{d_{i}}$ に依存しない項をすべて消去する と以下のようになる。

$$
\begin{aligned}
& \mathcal{C}_{d_{i}}\left(x_{d_{i}}(t), x_{-d_{i}}(t)\right) \\
= & v_{i}\left(x_{d_{i}}(t)\right)-\lambda_{i}(t) x_{d_{i}(t)} \\
& +\left(\boldsymbol{E}_{i} \boldsymbol{z}_{i}(t)+\boldsymbol{C}_{i} x_{s_{i}}(t)-\frac{1}{2} \boldsymbol{C}_{i} x_{d_{i}}(t)\right. \\
& \left.+\sum_{j \in \mathcal{N}_{i}} \boldsymbol{E}_{i j} \boldsymbol{z}_{j}(t)+\boldsymbol{C}_{i} w_{i}(t)\right)^{T} \boldsymbol{Q}_{i} \boldsymbol{C}_{i} x_{d_{i}}(t)
\end{aligned}
$$

供給者についても同様に考える，なお，ここで定める供給 量 $x_{s_{i}}$ は, 実際に需要家に提供することで利益を得るための 供給量としている，実際には，需要と供給がずれると系統は 不安定となってしまうため，供給者は常に LFCによる調整 を行なわなければならない，調整にかかったコストは，系統 を維持するための義務として，ISO から支払われるものとす る。この設定のもとで, 定理 1 に従って，付加コストを計算 すると, 供給者の新たな利益関数 $\mathcal{C}_{s_{i}}\left(x_{s_{i}}(t), x_{-s_{i}}(t)\right)$ は以下 のようになる。

$$
\begin{aligned}
& \mathcal{C}_{s_{i}}\left(x_{s_{i}}(t), x_{-s_{i}}(t)\right) \\
= & -c_{i}\left(x_{s_{i}}(t)\right)+[J \circ H]\left(x_{s_{i}}(t), x_{-s_{i}}(t)\right) \\
& +\boldsymbol{\lambda}^{T}(t) \boldsymbol{g}\left(x_{s_{i}}(t), x_{-s_{i}}(t)\right)+F_{s_{i}}\left(x_{-i}, \boldsymbol{\lambda}\right)
\end{aligned}
$$

同様に, $[J \circ H]\left(x_{s_{i}}, x_{-s_{i}}\right)$ と $\boldsymbol{g}\left(x_{s_{i}}, x_{-s_{i}}\right)$ を展開し, 任意 関数 $F_{i}\left(x_{-s_{i}}, \boldsymbol{\lambda}\right)$ を用いて $x_{s_{i}}$ に依存しない項をすべて消去 すると以下のようになる.

$$
\begin{aligned}
& \mathcal{C}_{s_{i}}\left(x_{s_{i}}(t), x_{-s_{i}}(t)\right) \\
= & -c_{i}\left(x_{s_{i}}(t)\right)+\lambda_{i}(t) x_{s_{i}}(t) \\
& -\left(\boldsymbol{E}_{i} \boldsymbol{z}_{i}(t)-\frac{1}{2} \boldsymbol{C}_{i} x_{s_{i}}(t)+\boldsymbol{C}_{i} x_{d_{i}}(t)\right. \\
& \left.+\sum_{j \in \mathcal{N}_{i}} \boldsymbol{E}_{i j} \boldsymbol{z}_{j}(t)+\boldsymbol{C}_{i} w_{i}(t)\right)^{T} \boldsymbol{Q}_{i} \boldsymbol{C}_{i} x_{s_{i}}(t)
\end{aligned}
$$

最後に，エリア $i$ のSO のコスト関数は以下のように表わ される。

$$
\mathcal{O}_{i}\left(\lambda_{i}(t), x_{i}(t)\right)=\lambda_{i}(t)\left(x_{s_{i}}(t)-x_{d_{i}}(t)+w_{i}(t)\right)
$$

ここで, 公共利益 $\boldsymbol{z}$, 需要量 $x_{d}$, および供給量 $x_{s}$ の変動 に合わせて, 各プレイヤーがいかにして, ナッシュ均衡解に 至るかという動的モデルを考えたい。本稿においてはアロー =ハーヴィッチの Gradient Method ${ }^{16)}$ の定差方程式を用い て, 需要家と供給者の行動をモデル化する.

$$
\begin{aligned}
x_{i}(t+1)= & \max \left\{0, x_{i}(t)+\gamma_{i} \frac{\partial \mathcal{C}_{i}(\boldsymbol{x}(t), \boldsymbol{\lambda}(t))}{\partial x_{i}(t)}\right\} \\
= & \max \left\{0, x_{i}(t)+\gamma_{i} \frac{\partial}{\partial x_{i}}\left(J_{i}\left(x_{i}(t)\right)\right.\right. \\
& \left.\left.+[J \circ H](\boldsymbol{x}(t))+\boldsymbol{\lambda}^{T}(t) g(\boldsymbol{x}(t))\right)\right\} \\
\lambda_{j}(t+1)= & \max \left\{0, \lambda_{j}(t)-\gamma_{j} \frac{\partial \mathcal{O}_{j}(\boldsymbol{x}, \boldsymbol{\lambda})}{\partial \lambda_{j}}\right\} \\
= & \max \left\{0, \lambda_{j}(t)-\gamma_{j} g_{j}(\boldsymbol{x}(t))\right\}
\end{aligned}
$$


(40) 式に示すアルゴリズムに従って, 各プレイヤーおよびオ ペレータが状態量を更新する結果, 状態量 $\boldsymbol{x}$ およびラグラン ジュ乗数 $\boldsymbol{\lambda}$ は鞍点解 $\left(\boldsymbol{x}^{*}, \boldsymbol{\lambda}^{*}\right)$ 近傍へと収束する。ただし, 近 傍は定数 $\epsilon>0$ が与えられたとき，(41) 式で定義される.

$$
\left\|\boldsymbol{x}(t)-\boldsymbol{x}^{*}\right\|^{2}+\left\|\boldsymbol{\lambda}(t)-\boldsymbol{\lambda}^{*}\right\|^{2} \leq \epsilon
$$

定差方程式 (40) 式をプライシングを考慮した利益関数 $\mathcal{C}_{d_{i}}\left(x_{d_{i}}(t), x_{-d_{i}}(t)\right), \mathcal{C}_{s_{i}}\left(x_{s_{i}}(t), x_{-s_{i}}(t)\right)$ に適用すると, 工 リア $i$ の需要量, 供給量の更新則がそれぞれ以下のように与 えられる。

$$
\begin{aligned}
x_{d_{i}}(t+1) & =x_{d_{i}}(t)+\gamma_{d i}\left(v_{i}^{\prime}\left(x_{d_{i}}(t)\right)-\lambda_{i}(t)+\boldsymbol{C}_{i}^{T} \boldsymbol{Q}_{i} \boldsymbol{E}_{i} \boldsymbol{z}_{i}(t)\right. \\
& +\boldsymbol{C}_{i}^{T} \boldsymbol{Q}_{i} \boldsymbol{C}_{i} x_{s_{i}}(t)-\boldsymbol{C}_{i}^{T} \boldsymbol{Q}_{i} \boldsymbol{C}_{i} x_{d_{i}}(t) \\
& \left.+\boldsymbol{C}_{i}^{T} \boldsymbol{Q}_{i} \boldsymbol{C}_{i} w_{i}(t)+\sum_{j \in \mathcal{N}_{i}} \boldsymbol{C}_{i}^{T} \boldsymbol{Q}_{i} \boldsymbol{E}_{i j} \boldsymbol{z}_{j}(t)\right)(42) \\
x_{s_{i}}(t+1) & =x_{s_{i}}(t)+\gamma_{s i}\left(\lambda_{i}(t)-c_{i}^{\prime}\left(x_{s_{i}}(t)\right)-\boldsymbol{C}_{i}^{T} \boldsymbol{Q}_{i} \boldsymbol{E}_{i} \boldsymbol{z}_{i}(t)\right. \\
& -\boldsymbol{C}_{i}^{T} \boldsymbol{Q}_{i} \boldsymbol{C}_{i} x_{s_{i}}(t)+\boldsymbol{C}_{i}^{T} \boldsymbol{Q}_{i} \boldsymbol{C}_{i} x_{d_{i}}(t) \\
& \left.-\boldsymbol{C}_{i}^{T} \boldsymbol{Q}_{i} \boldsymbol{C}_{i} w_{i}(t)-\sum_{j \in \mathcal{N}_{i}} \boldsymbol{C}_{i}^{T} \boldsymbol{Q}_{i} \boldsymbol{E}_{i j} \boldsymbol{z}_{j}(t)\right)
\end{aligned}
$$

(42), (43) 式であるが, 定理 1 に従って付加コストが計算 されれば, 任意関数の構造にかかわらずこれら 2 式が定差方 程式により導出される。このことは，任意関数はプレイヤー の戦略に影響を与えないことを表わしている，最後に，エリ ア $i$ のSOによりなされる価格の更新則は以下で与えられる.

$$
\lambda(t+1)=\lambda(t)+\gamma_{o_{i}}\left(x_{d_{i}}(t)-x_{s_{i}}(t)-w_{i}(t)\right)
$$

\section{4. シミュレーション検証}

まずはシミュレーションに関して設定した情報を整理する.

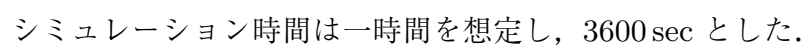
シミュレーション時間内における両エリアにおける風力発電 機の出力変動は以下の Fig. 4, Fig. 5 とした. 各エリアにお いてエリア 1 ならば $1000 \mathrm{sec}$ から，2000 sec の間，エリア 2 ならば $1500 \mathrm{sec}$ から $2500 \mathrm{sec}$ の間に大きな出力変動が生じ, 過剩供給となるが，プライシングを適切に行なうことで，系 統に与える影響を最小限に抑えたい。

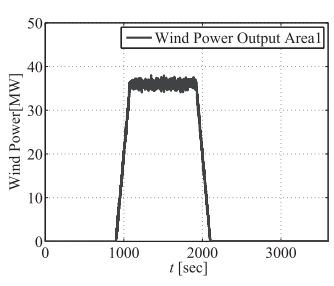

Fig. 4 Wind power output of area 1

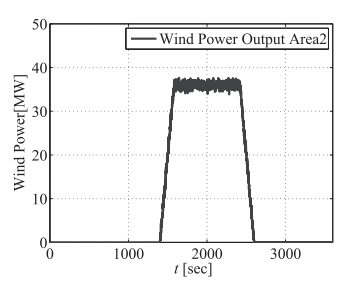

Fig. 5 Wind power output of area 2
また，エリア $i$ の需要家の効用関数と，供給者のコスト関 数をそれぞれ以下のように設定する.

$$
v_{i}\left(x_{d_{i}}(t)\right)=a_{i} \log \left(x_{d_{i}}(t)\right), c_{i}\left(x_{s_{i}}(t)\right)=\frac{1}{2} b_{i} x_{s_{i}}^{2}(t)
$$

$a_{i}, b_{i}$ はそれぞれ, $a_{1}=1.900 \times 10^{6}, a_{2}=1.999 \times 10^{6}$, $b_{1}=b_{2}=1.922 \times 10^{2}$ とした. 効用関数, コスト関数のパラ メータがこのようになり, 電力価格を $1.730 \times 10^{4}$ yen $/ \mathrm{MW}$ とし $, x_{d_{i}}^{\prime}, x_{s_{i}}^{\prime}$ であったとき，おのおのにとって最適な需要 量, あるいは供給量は, $x_{d_{1}}^{\prime}=110 \mathrm{MW}, x_{d_{2}}^{\prime}=115 \mathrm{MW}$, $x_{s_{1}}^{\prime}=x_{s_{2}}^{\prime}=90 \mathrm{MW}$ となる.つまり，プライシングがな ければ両エリアにおいて需要量のほうが高い值となる，定差 方程式のステップサイズはエリア $i$ の需要家のステップサイ ズを $\gamma_{d i}=5.0 \times 10^{-4}$, 供給者と ISO のステップサイズを $\gamma_{s i}=\gamma_{o i}=5.0 \times 10^{-3}$ とした. つぎに, 社会厚生関数 $J(\boldsymbol{z})$ における行列 $\boldsymbol{Q}$ に関してであるが，これは ISO が周波数変 動などの公共利益の变動にどれだけの重みを設けるかという 指標として考えることができ, $\boldsymbol{Q}=2.0 \times 10^{8} \boldsymbol{I}_{5}$ に設計した.

シミュレーション検証は, ISO による付加コスト $\pi_{i}$ の有 効性を検証するため, 三つのパターンに分けて行なう。提案 法は, 各プレイヤーの利益関数が (36), (38) 式で与えられ, 更新則は，(42)，(43) 式で行なわれる，パターン 1 は，主に 価格 $\lambda$ の更新による効果を検証するもので，各プレイヤーの 利益関数と更新則が, 以下のように与えられた場合を考える.

$$
\begin{aligned}
& \mathcal{C}_{d_{i}}\left(x_{d_{i}}(t), x_{-d_{i}}(t)\right)=v_{i}\left(x_{d_{i}}(t)\right)-\lambda_{i}(t) x_{d_{i}}(t) \\
& \mathcal{C}_{s_{i}}\left(x_{s_{i}}(t), x_{-s_{i}}(t)\right)=-c_{i}\left(x_{s_{i}}(t)\right)+\lambda_{i}(t) x_{s_{i}}(t) \\
& x_{d_{i}}(t+1)=x_{d_{i}}(t)+\gamma_{d i}\left(v_{i}^{\prime}\left(x_{d_{i}}(t)\right)-\lambda_{i}(t)\right) \\
& x_{s_{i}}(t+1)=x_{s_{i}}(t)+\gamma_{s i}\left(\lambda_{i}(t)-c_{i}^{\prime}\left(x_{s_{i}}(t)\right)\right)
\end{aligned}
$$

パターン 2 は, 価格を $\lambda_{c}=1.730 \times 10^{4}$ yen $/ \mathrm{MW}$ で固定し, 付加コスト $\pi_{i}$ を与えた場合における効果を検証するもので, 各プレイヤーの利益関数と更新則が，以下のように与えられ た場合を考える。

$$
\begin{aligned}
& \mathcal{C}_{d_{i}}\left(x_{d_{i}}(t), x_{-d_{i}}(t)\right) \\
= & v_{i}\left(x_{d_{i}}(t)\right)-\lambda_{c} x_{d_{i}}(t) \\
& +\left(\boldsymbol{E}_{i} \boldsymbol{z}_{i}(t)+\boldsymbol{C}_{i} x_{s_{i}}(t)-\frac{1}{2} \boldsymbol{C}_{i} x_{d_{i}}(t)\right. \\
& \left.+\sum_{j \in \mathcal{N}_{i}} \boldsymbol{E}_{i j} \boldsymbol{z}_{j}(t)+\boldsymbol{C}_{i} w_{i}(t)\right)^{T} \boldsymbol{Q}_{i} \boldsymbol{C}_{i} x_{d_{i}}(t) \\
& \mathcal{C}_{s_{i}}\left(x_{s_{i}}(t), x_{-s_{i}}(t)\right) \\
= & -c_{i}\left(x_{s_{i}}(t)\right)+\lambda_{c} x_{s_{i}}(t) \\
& -\left(\boldsymbol{E}_{i} \boldsymbol{z}_{i}(t)-\frac{1}{2} \boldsymbol{C}_{i} x_{s_{i}}(t)+\boldsymbol{C}_{i} x_{d_{i}}(t)\right. \\
& \left.+\sum_{j \in \mathcal{N}_{i}} \boldsymbol{E}_{i j} \boldsymbol{z}_{j}(t)+\boldsymbol{C}_{i} w_{i}(t)\right)^{T} \boldsymbol{Q}_{i} \boldsymbol{C}_{i} x_{s_{i}}(t) \\
& x_{d_{i}}(t+1)=x_{d_{i}}(t)+\gamma_{d i}\left(v_{i}^{\prime}\left(x_{d_{i}}(t)\right)+\boldsymbol{C}_{i}^{T} \boldsymbol{Q}_{i} \boldsymbol{E}_{i} \boldsymbol{z}_{i}(t)\right. \\
& \quad+\boldsymbol{C}_{i}^{T} \boldsymbol{Q}_{i} \boldsymbol{C}_{i} x_{s_{i}}(t)-\boldsymbol{C}_{i}^{T} \boldsymbol{Q}_{i} \boldsymbol{C}_{i} x_{d_{i}}(t) \\
& \left.+\boldsymbol{C}_{i}^{T} \boldsymbol{Q}_{i} \boldsymbol{C}_{i} w_{i}(t)+\sum_{j \in \mathcal{N}_{i}} \boldsymbol{C}_{i}^{T} \boldsymbol{Q}_{i} \boldsymbol{E}_{i j} \boldsymbol{z}_{j}(t)\right)
\end{aligned}
$$




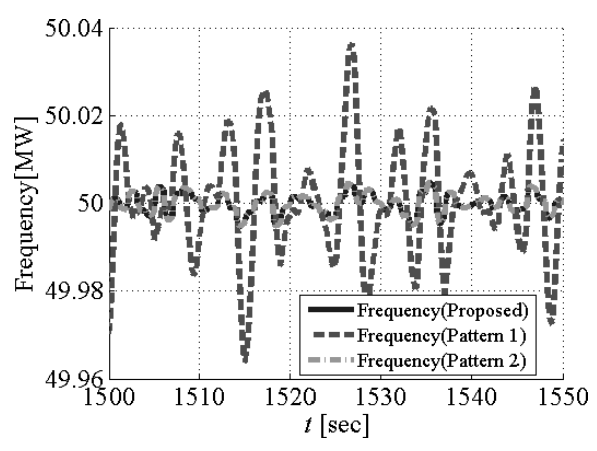

Fig. 6 Load frequency $n$ area 1

$$
\begin{aligned}
x_{s_{i}}(t+1) & =x_{s_{i}}(t)+\gamma_{s i}\left(-c_{i}^{\prime}\left(x_{s_{i}}(t)\right)-\boldsymbol{C}_{i}^{T} \boldsymbol{Q}_{i} \boldsymbol{E}_{i} \boldsymbol{z}_{i}(t)\right. \\
& -\boldsymbol{C}_{i}^{T} \boldsymbol{Q}_{i} \boldsymbol{C}_{i} x_{s_{i}}(t)+\boldsymbol{C}_{i}^{T} \boldsymbol{Q}_{i} \boldsymbol{C}_{i} x_{d_{i}}(t) \\
& \left.-\boldsymbol{C}_{i}^{T} \boldsymbol{Q}_{i} \boldsymbol{C}_{i} w_{i}(t)-\sum_{j \in \mathcal{N}_{i}} \boldsymbol{C}_{i}^{T} \boldsymbol{Q}_{i} \boldsymbol{E}_{i j} \boldsymbol{z}_{j}(t)\right)
\end{aligned}
$$

シミュレーションの結果は Fig. 6〜Fig. 10 のようになっ た. Fig. 6 はエリア 1 に扔り系統周波数偏差をプロットし たものである，各パターンにおける結果を見ると，提案法と パターン 2 はパターン 1 の結果と比較して, 周波数の変動を 十分に抑えていることがわかる。これは, 公共利益を各プレ イヤーに付加コストとして与えた結果, 公共利益の達成がな されていることを示している. Fig. 7 はエリア 1 における需 要と供給の偏差をプロットしたものである。ここで生じた偏 差は, LFC 発電機の出力調整により埋めなければならないた め, 少なければ少ないほうが望ましい。結果を見ると，提案手 法とパターン 1 では, 偏差が徐々に収束に向かっていること がわかる. また, Fig. 6, Fig. 7 両方の結果から, 提案したプ ライシング手法は, 公共利益である周波数偏差の制御と, 負荷 平準化制御を両立できることがわかる．Fig. 8 はエリア 1 に おける需要家の効用をプロットしたものである，結果を見る と, 提案法はパターン 1 と比較して, 常に需要家にとって高い 満足度が維持できていることがわかる．ところが，入を固定 した場合であるパターン 2 と比較すると, 効用が低くなって しまう場合があることがわかる。この理由は，Fig. 10 を見れ ば明らかであり, 需要が供給に比べて大きくなる時間におい て需要を抑えるために価格が増大し, 需要家にとっての金銭 的負担が大きくなってしまうためだと考えられる.Fig. 9 は 供給者が得る利益を表わしており，Fig. 8 と比較すると，お 互いに相反していることがわかる，供給者においても提案法 はパターン 1 よりも多くの利益を得ているため, 提案法の結 果は, 社会全体でみるとより多くの金銭的利益を得ているこ とがわかる。

\section{5.おわりに}

本稿では，等式制約の存在する最適化問題において, 各プレ イヤーの利己的な行動を公共的な利益へと誘導するプライシ ング手法を提案した。 まず，一般的な最適化問題として原問

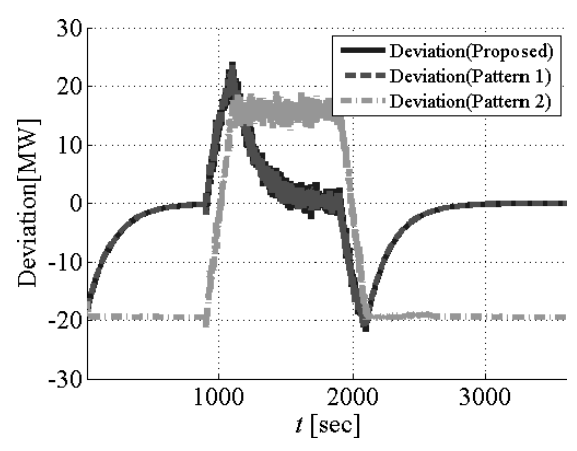

Fig. 7 Demand and supply deviation in area 1 except LFC output

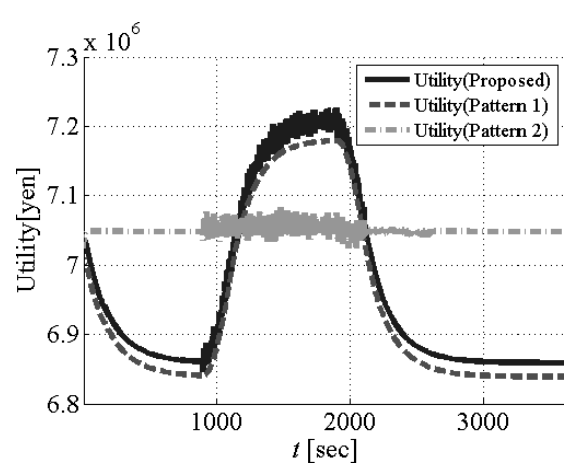

Fig. 8 Consumer utility in area 1

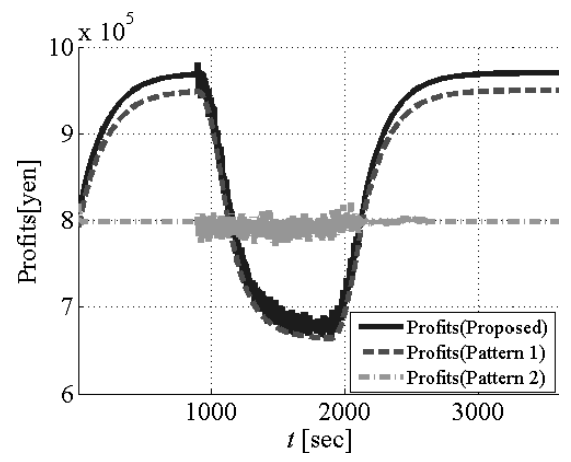

Fig. 9 Suplier profit in area 1

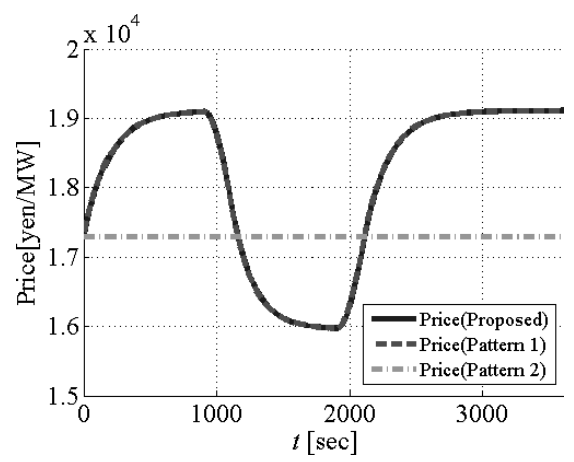

Fig. 10 Price of area 1

題を定式化し，ゲーム問題となるよう分散化を行なった。 そ して, 原問題と分散化した問題の解が一致するようなプライ シングの条件を示した。つぎに，提案したプライシング手法 
の, 電力網の系統周波数制御問題への適用について考察した. 最後に, シミュレーションによって, 提案手法の有効性を確 認した.

その結果，プライシングを行なうことによって，系統周波 数, すなわち公共利益の安定化を達成できた. さらに, 需要 と供給の偏差が打ち消されていることから, 制約条件下での 最適化を達成していることがわかる，これらの結果は，本稿 における提案手法が, 従来法では達成していなかった, 原問 題の最適化と, 制約条件の達成ができることを示しており, 幅広い問題に適用することが可能な手法といえる。ところが, 電力価格 $\lambda$ の更新により, 需要家と供給者が得る利益に差が できてしまうことがあり，場合によってはどちらか一方が不 利益を被る可能性がある.

今後の課題として, どちらか一方が不利益を被るケースに おいてもある程度の利益を参加プレイヤーに対して保証する ような任意関数 $F_{i}$ の設定に関する考察などがあげられる。ま た, 本研究では離散化の周期と需要量, 供給量, 価格の更新 周期を同一としているが，それぞれの応答時間を考慮した更 新周期の検討も必要である。

\section{参 考 文 献}

1) T. Namerikawa, T. Hatanaka and M. Fujita: On Predictive Control for Systems with Information Structured Constraints, SICE Journal of Control Measurement and System Integration, 4-6, 452/459 (2011)

2) C.E. Fosha and O.I. Elgerd: The Megawatt-Frequency Control Problem: A New Approach via Optimal Control Theory, IEEE Transactions on Power Apparatus and Systems, 89-4, 563/577 (1970)

3）滑川 徹: スマートグリッドのための分散予測制御, 計測と制 御, 51-1, 62/68 (2012)

4) T. Namerikawa and T. Kato: Distriburted Load Frequency Control of Electrical Power Networks via Interative Gradient Method, IEEE Conference on Decision and Control and European Control Conference, 7723/7726 (2011)

5) 入江, 横山, 多田: 大容量風力発電機導入時における需要家 ヒートポンプ給湯器と蓄電池の協調による系統周波数制御, 電 気学会論文誌 B, 130-3, 338/446 (2010)

6) Y. Miyano and T. Namerikawa: Load Leveling Control by Real-Time Dynamical Pricing Based on Steepest Descent Method, SICE Annual Conference, 131/136 (2012)

7) M. Roozbehani, M.A. Dahleh and S.K. Mitter: Volatility of Power Grids under Real-Time Pricing, IEEE Transactions on Power Systems, 27-4, 1926/1940 (2012)

8) A.W. Berger and F.C. Schweppe: Real time pricing to assist in load frequency control, IEEE Transaction on Power Systems, 4-3, 920/926 (1989)

9) A. Jokić, M. Lazar and P. van den Bosch: Real-Time control of power systems using nodal prices, International Journal of Electrical Power and Energy Systems, 31-9, $522 / 530(2009)$

10) F.L. Alvarado, J. Meng, C.L. DeMarco and W.S. Mota: Stability Analysis of Interconnected Power Sytems Coupled With Market Dynamics, IEEE Transactions on Power Systems, 16-4, 695/701 (2001)

11) T. Tanaka and C. Langbort: Linear Quadratic Optimal Controller Design for Effective Price Mechanisms Using Limited Market Information, 2nd IFAC Workshop on Dis- tributed Estimation and Control in Networked Systems, $311 / 316$ (2010)

12）平田, 内田：分散化と統合化の制御理論, 計測と制御, 51-1, $55 / 61(2012)$

13) T. Tanaka, A. Cheng and C. Langbort: A Dynamic Pivot Mechanism with Application to Real Time Pricing in Power Systems, American Control Conference, 3705/3711 (2012)

14) A. Rantzer: Dynamic Dual Decompositon for Distributed Control, American Control Conference, 884/888 (2009)

15) T. Senju: A frequency control approach by decentralized generators and loads in power systems, Power Energy Conference, 79-84 (2008)

16) K.J. Arrow, L. Hurwicz and H. Uzawa: Studies in Linear and Nonlinear Programming, Stanford Univercity Press (1958)

|

$$
\text { [著 者 紹 介] }
$$

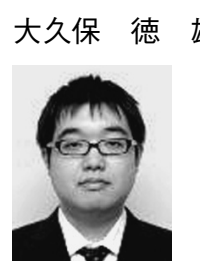

2011 年慶應義塾大学理工学部システムデザイン 工学科卒業. 同年同大学大学院理工学研究科総合 デザイン工学専攻に入学, 現在に至る. 電力のリ アルタイムプライシングに関する研究に従事.

\section{佐 藤 隆太郎}

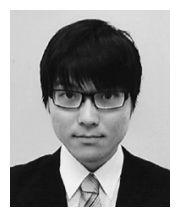

2013 年慶應義塾大学理工学部システムデザイン 工学科卒業.

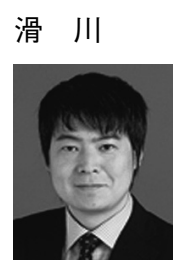

徹（正会員）

1994 年金沢大学大学院自然科学研究科システム 科学専攻博士課程中退. 同年金沢大学工学部電気. 情報工学科助手. 同講師を経て 2002 年長岡技術 科学大学機械系助教授. 2006 年金沢大学大学院自 然科学研究科電子情報科学専攻助教授を経て 2007 年同大学理工学研究域電子情報学系准教授. 2009 年より慶應義塾大学理工学部システムデザイン工 学科准教授となり現在に至る。 2012 年より JST 藤田 CREST 内田チームに扔いて, 分散制御と統 合メカニズムに関する研究を推進する。ロバスト 制御理論, 分散協調制御理論とその電力ネットワー ク制御への応用に関する研究に従事. 博士 (工学). システム制御情報学会, IEEE などの会員. 